\title{
レーザー局所加熱法による材料組織制御
}

\author{
柴柳 敏哉, 塚本 雅裕, 阿部 信行 \\ 大阪大学 接合科学研究所 ( $5567-0047$ 大阪府茨木市美穂ケ丘11-1)
}

\section{Microstructure Control by Laser Spot Heating}

Toshiya SHIBAYANAGI, Masahiro TSUKAMOTO, and Nobuyuki ABE

Joining and Welding Research Institute, Osaka University, 11-1 Mihogaoka, Ibaragi, Osaka 567-0047

(Received July 24, 2007)

\begin{abstract}
The newly developed laser spot heating system is explained regarding a concept of heterogeneity in polycrystalline microstructure. The present heating system enables a collimated laser beam focus on specimen surface with a diameter less than $10 \mu \mathrm{m}$. Effectiveness of the present spot heating method is verified as follows. The spot heating yielded a cluster composed of recrystallized grains in the deformed matrix. Size of the cluster is around $160 \mu \mathrm{m}$ and this artificial microstructure has never been reported so far. The spot heating system can lock-on any target areas to be shot, and five-spot heating was performed to show five clusters having grains with different orientations. Texture control is also expected to be realized by the present heating system. These new findings strongly suggest that the spot heating method with a heating area comparative to the size of microstructure parameters such as grains, second phase, particles and even dense dislocation walls will enables us to fabricate peculiar microstructures that we design.
\end{abstract}

Key Words: Fiber-laser, Spot heating, Pure aluminum sheet, Recrystallization, Orientation distribution

1.はじめに

材料組織とは固体(材料)空間の分割様式の総称である. 金属材料を例に挙げると，結晶界面で区切られた領域内に 析出物，介在物，転位や点欠陥などが分散している1 料学に扔ける組織制御とはこれら空間分割要素(組織の構 成要素)の存在状態を最適化することを意味する。

組織制御に用いられるエネルギーには力学エネル ギー, 熱エネルギー, 電気エネルギーなどがあり，それ ぞれ絶妙の制御プロセス技術が駆使されている。これら のエネルギーは多くの材料創成プロセスに扔いて素材の 広い範囲に均一に投入されるが, 近年, 組織の構成要素 の一つである結晶粒の大きさと同程度の領域に熱エネル ギーを集中させることができるレーザーシステムが登場 し，局所空間の組織制御という新しい概念の創出をもた らした2).

本稿では，筆者の研究グループにて最近開発された レーザー局所加熱システムによる組織制御について，工 業用純アルミニウムを用いた実験結果を紹介しながら， その意義と可能性について解説する。

\section{2. 材料組織の構成要素と空間的分布状態の多様性}

\section{金属材料やセラミックス材料の多くは多結晶組織を有}

する，多結晶組織の構成要素としては，相の種類，結晶粒 の形と大きさ，結晶粒の結晶学的方位ならびに結晶界面な どがあり，それぞれ材料特性に重要な影響を及ぼすことが 知られている。例えば結晶粒の大きさや第2 相粒子の存在 状態は降伏応力などの力学特性に支配的な影響を及はし, 結晶方位は塑性変形挙動や加工性に直接的に関与する組織 要素である.

これら組織要素の存在状態を記述する方法には統計的分 布と空間的分布の二つの表現法がある。前者の場合は結晶 粒の大きさを「平均結晶粒径」のようにあるスカラー量で対 象とする組織要素の状態を代表したり，あるいは「結晶粒 度分布」のようにヒストグラム表示で分布状態を表現した りする.

これに対して空間的分布状態の場合は, 各組織要素の状 態を材料内の位置の関数として表現する。この概念は結晶 粒方位分布や集合組織了)を議論する場合に有用で, Fig. 1に Al-Mg合金再結晶材 $(773 \mathrm{~K}-1 \mathrm{ks}$.$) の)組織解析に空間的方位$ 分布の概念を適用した例を示す4). Fig. 1 (a) は全体の結晶 方位分布を各結晶粒に配された色は標準三角形で示される 結晶方位に対応させて表示している。例えば赤, 青, 緑の 各色はそれぞれ板面方位が[100]，[110]および[111]である ことを示しており, その他の方位はこれら基準色の混色で 表現されている。このような組織状態の表現法を結晶方位 マップと呼ぶ. 図より, 特定の方位への方位集積は認めら 

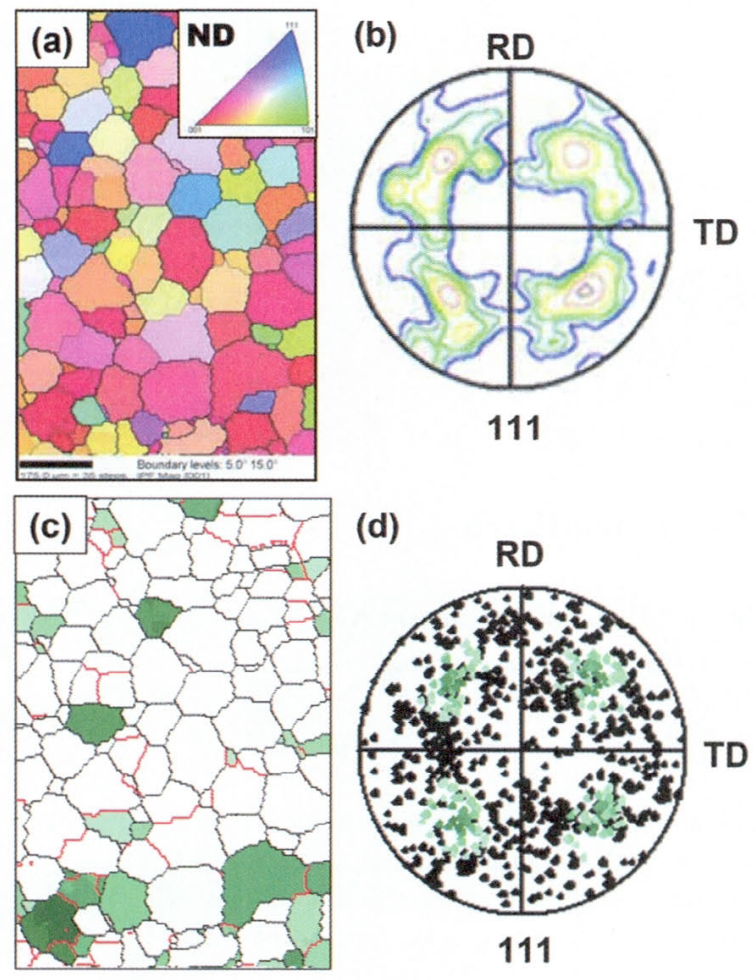

Fig. 1 Orientation maps of Al-4 mass\%Mgalloy sheet recrystallized at $773 \mathrm{~K}$ for $1 \mathrm{ks}$. (a) Orientation map of whole measured area. (b) (111)-pole figure of whole measured area. (c) Highlighting of cube oriented grains. (d) (111)-pole figure highlighting cube orientation.

れていないことがわかる.このことは (b)に示した正極点 図からも理解できる。なお，正極点図は統計的方位分布 の代表的な表示法である.

Fig. 1 (c) は (a)の中から立方体方位 (圧延方向が[001]で, 板面方向)が[100])からの偏差角度が15度以内の方位成分 を持つ結晶粒のみを抽出して着色表示した結果である。

図上り，孤立して存在する場合や，いくつかの同一方位 結晶粒が隣接しあってクラスターを形成している場合が 見て取れる.この解析結果は, 結晶方位分布は空間的分 布という観点で眺めると決して均一ではなく, 材料内の それぞれの場所によって異なる様相を呈することを示し ている.

このように材料組織は統計的には均一に見えても局所 的に見ると不均一な分布状態にある。すなわち，同じ製 造ロットの素材であっても完全に同じ空間的分布状態で あることはほとんどない.この材料組織の多様性が次節 で述べる局所組織制御技術開拓の出発点となっている。

\section{3. 局所組織制御の必要性}

材料組織を制御する目的は，それぞれの素材に対して 要求される特性を満足することにある。この目的のため に我々は力学エネルギーや熱エネルギーなどを素材に投 入して内部状態を最適化する.これを一般的に加工・熱 処理などと呼び, 今日我々が利用している素材の全てが 加工・熱処理技術の恩恵を受けているといっても過言で
はない，熱処理プロセスの多くは厳密に制御された均一 な温度場にて行われることが多い。これは，不均一な空 間的分布状態にある組織要素から成る材料組織に対して 均一な温度場を与えることを意味している。ここで懸念 されることは, 設計された組織状態を現出する過程にお いて, 不必要な組織要素までも組織変化に関与させてし まい, その結果として目的とする組織状態を完全に実現 できないことである。

例えば，結晶粒成長現象では局所的な組織状態が全体 の組織変化に重要な影響を及ばす5,6)。この現象では結晶 粒界の移動が基調となるが, 粒界移動はその粒界の周囲 にある結晶粒の相対的な大きさの違いや結晶粒界の構造 に起因する移動度などの極めて局所的な組織状態を反映 して移動方向と速度が決まる。したがって, 空間的に不 均一な粒径分布, 方位分布や粒界構造分布を持つ組織に 対して素材内全ての領域を等しく加熱するということ は，成長させたい方位を持つ結晶粒の選択的成長を必ず しも実現できない. 隣の領域でたまたま成長してきた結 晶粒の干渉を受けるからである。

Fig. 2に結晶粒成長の計算機シミュレーションの一例を 示す7).ここでは予め特定の結晶粒のみを優先成長させた 状態を初期状態として均一温度場での組織变化を計算し た. 計算には純アルミニウムのパラメータを採用し，3 種 類の温度で計算した。図より，いずれの温度において も, 予め周囲の結晶粒よりも大きくしておけばその後の 均一温度場において消滅することなく成長を続けること ができることが示されている。

このように, 材料組織で特定の位置にある結晶粒を選 択的に成長させておくことは組織設計において有効であ る。あたかも囲碁における定石のように, 全体の組織変 化に対してポイントになる引き金を引くような領域の組 織だけを優先的に発達させておくことで我々は望みの組 織状態を創り出せる可能性がある。また, 空間的な組織 要素の配置状態がそれぞれの局所領域において必然的な 組織変化を進行させて全体の組織が変化していく様は生 物が親から受け継いだ遺伝情報を基にして成長すること にも例えることができよう.

すなわち，局所組織制御とは一連の製造プロセスを反 映して造り込まれた材料組織情報の中で目的とする位置 の組織状態だけを選択的かつ意図的に変化させることで 全体の組織変化を制御する技術を言い, 材料組織の遺伝 子治療とも言える。

\section{4.レーザー援用局所加熱システムの設計}

局所加熱の対象となる材料組織の大きさは, 結晶粒を 制御対象とする場合は, 数ミクロンから数十ミクロン程 度までの範囲である，他の組織要素である析出物やさら に小さな格子欠陥などをターゲットにする場合にはさら に小さな領域のみに熱エネルギーを集中させる必要があ る.

本解説では加工組織の中に再結晶粒を創り出すことを 題材とする．再結晶とは加工によって導入されたひずみ 
(a)

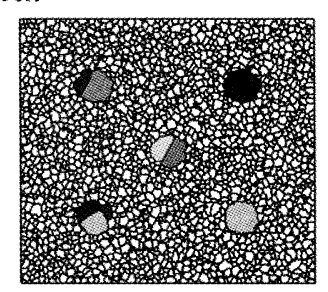

(a) $50 \mathrm{mcs}$

$850 \mathrm{~K}$

(b)

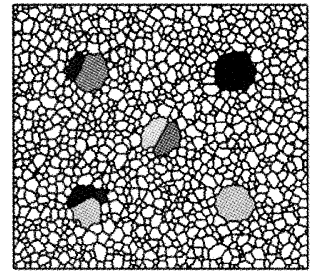

(d) $50 \mathrm{mcs}$

900K

(c)

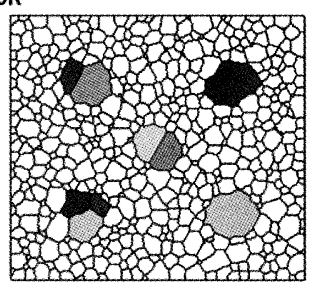

(g) $50 \mathrm{mcs}$

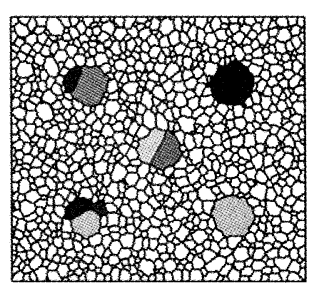

(b) $500 \mathrm{mcs}$

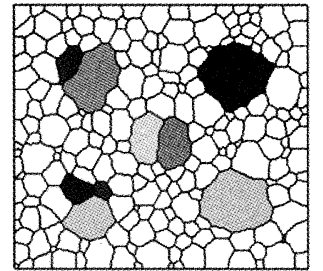

(e) $500 \mathrm{mcs}$

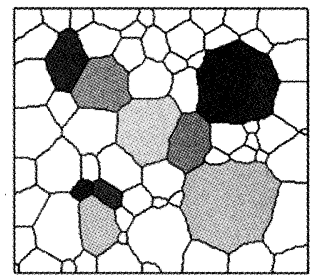

(h) 500 mcs

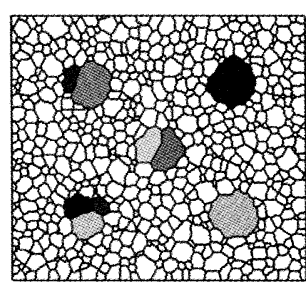

(c) $1000 \mathrm{mcs}$

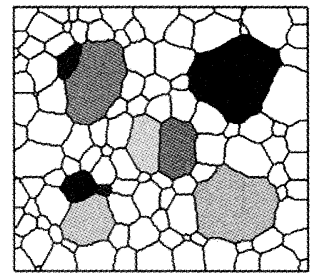

(f) $1000 \mathrm{mcs}$

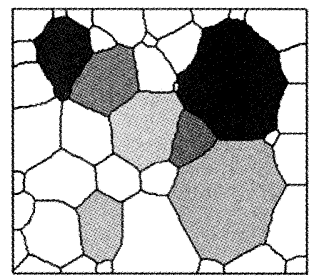

(i) $1000 \mathrm{mcs}$

Fig. 2 Monte Carlo simulation of grain growth process starting from a heterogeneous grain size distribution. The hatched grains had larger grain size in the initial structure of the simulation. (a) $800 \mathrm{~K}$, (b) $850 \mathrm{~K}$, (c) $900 \mathrm{~K}$.

を解消するために金属材料が自らの内部状態を変化させ ることによって生ずる材料組織学的現象である ${ }^{8)}$.

再結晶現象を局所的に進行させるにあたって局所加熱 領域の大きさは厳格に規定されるものではないが，再結 晶粒をできるだけ小さくすること, さらに特定の再結晶 粒のみを現出させることを最終的な目標としているた め, ここでは直径数ミクロン程度の領域にレーザー光を 集光するシステムを設計した。 システムが具備すべき必 要条件としては, シンプルな機構であること, エネル ギーロスを極力抑えて効率よく試料にエネルギー輸送で きることとしたが，この目的に合致するレーザー発振器 としてファイバレーザーを採用した。

Fig. 3に筆者のグループで設計したレーザー局所加熱シ ステムの概略図を示す. 光源は最大出力 $100 \mathrm{~W}$ のァイバ レーザー(IPG製，YLR-100SM)で，ミラーとレンズの組み 合わせにより試料表面において焦点を結ぶように光学系が 設計されている，焦点位置での理論的な最小ビーム径は5

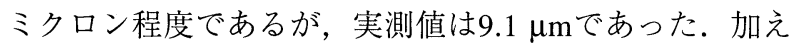
て, 本システムでは可視光による試料表面状態のリアル夕 イム観察ができる、レーザー照射は室温大気中で行ってい る. 筆者のグループではこのレーザー加熱システムのこと をファイバレーザー援用局所加熱システム (Fiber Laser Aided Spot Heating: FLASH) と呼んでいる.

\section{5. 純アルミニウムへの局所加熱の適用例9)}

Fig. 4に工業用純アルミニウム板 (板厚 $1 \mathrm{~mm}$ ) にレーザー

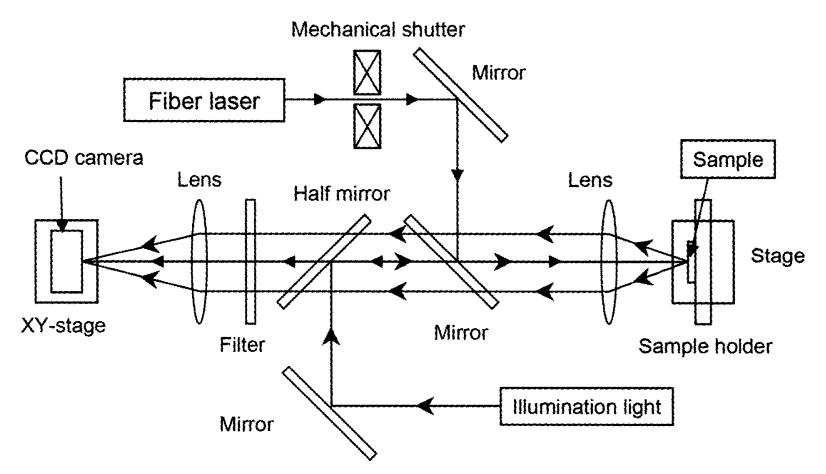

Fig. 3 Schematic illustration of the present laser heating system.

照射を施した時の表面状態の変化の走査電子顕微鏡観察 例を示した。レーザー光のエネルギー密度は $6.3 \times 10^{7}$ W/cm²である。（a)から (c) は照射時間がそれぞれ10秒，13 秒および 15 秒の場合の試料表面の二次電子像である。照 射時間が10秒の場合には (a)に見られるように表面状態の 変化は全く認められないが，13秒になると（b)に示したよ うに僅かなコントラストの変化が生じる，さらに照射時 間を長くして15秒とした場合には (c)に示したように明瞭 な凹みが出現している。これは，レーザー加熱により試 料表面近傍の温度が局所的に融点を超えて液相のアルミ ニウムが周囲に飛散した結果によると考えている．以 後, この凹みを溶融痕と呼ぶ，溶融痕の大きさは約 $10 \mu \mathrm{m}$ であり，この結果はFLASH 法では実際にこの程度の領域 に熱エネルギーを集中させることに成功したことを意味 する。なお，溶融痕が出現し始めるレーザー照射条件は 試料表面状態の影響を非常に強く受けて変化するので, 

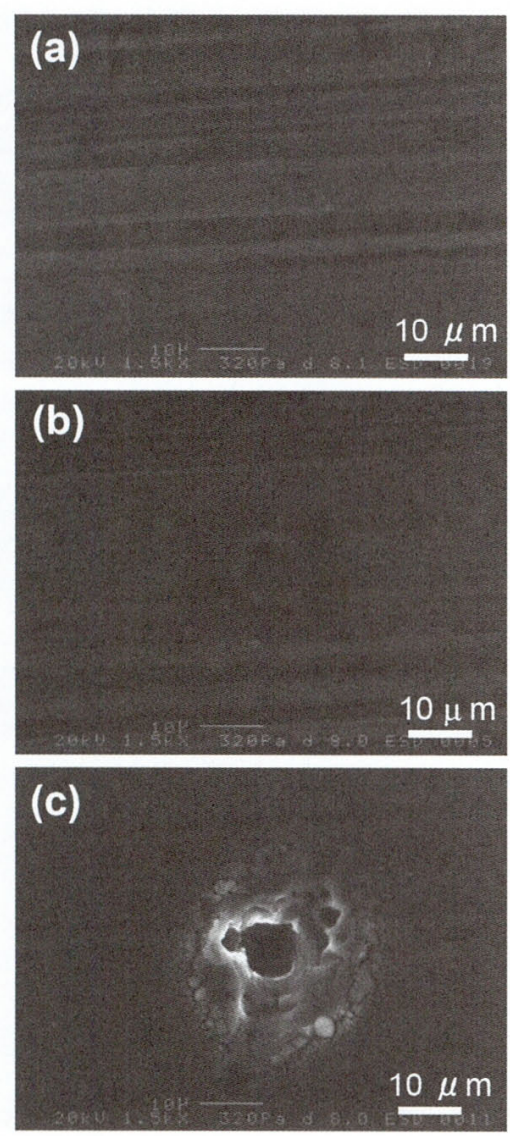

Fig. 4 Changes of surface morphology of pure Al plate under the laser spot heating with a power density of 6.3 $\times 10^{7} \mathrm{~W} / \mathrm{cm}^{2}$. (a) $10 \mathrm{~s}$, (b) $13 \mathrm{~s}$, and (c) $15 \mathrm{~s}$.

組織制御のための照射条件の精密化のためには良く制御 された表面状態を作る技術の確立が必要になる。

次に, 溶融痕が生じた条件で照射した時の試料表面を 化学研磨で取り除いてSEM-EBSP法10)にて組織解析を行っ た. 照射条件は $6.3 \times 10^{7} \mathrm{~W} / \mathrm{cm}^{2}$ で20 秒である. 結果をFig. 5 に示す。図中の色は前述の結晶方位に対応している。試 料は冷間圧延加工を施されているためにFig. 1に示したよ うな明瞭な結晶粒組織を示していない。これに対して, 図の中央部に花びら状に加工組織よりも大きな結晶粒群 が存在しているのがわかる。これらは明らかに再結晶粒 であり，局所加熱により創出されたものである。花びら 状再結晶粒群の中心部は溶融痕が残存した状態であるた めに解析不能となり明瞭な組織を呈していない. 再結晶 粒群の大きさは直径にして約 $160 \mu \mathrm{m}$ であり, 照射領域が $9 \mu \mathrm{m}$ 程度であることから, 溶融と熱伝導により照射領域 の18倍程度まで熱影響領域が拡大したことを示唆してい る。このような局所再結晶領域の大きさは照射条件で制 御可能であり, 対象となる材料の熱伝導度を考慮して, 照射位置の温度制御を精密に計測することができれば試 料表面に溶融領域を作ることなく照射領域とほぼ同等の 大きさの再結晶粒を作り出せるであろう.

Fig. 6はマルチスポット照射の一例である。この例では 照射位置を 5 力所選んで同一照射条件 $\left(7.0 \times 10^{7} \mathrm{~W} / \mathrm{cm}^{2}\right.$ で 14秒)で局所加熱処理を施している. 図より，照射位置そ れぞれで異なる再結晶粒群が出現していることがわかる

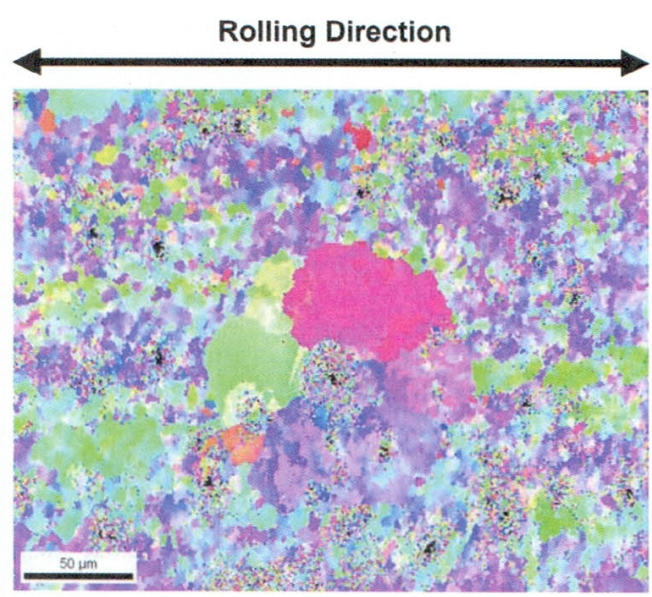

Fig. 5 Cluster of locally recrystallized grains in cold rolled pure aluminum plate. $\left(6.3 \times 10^{7} \mathrm{~W} / \mathrm{cm}^{2}-20 \mathrm{~s}\right)$.
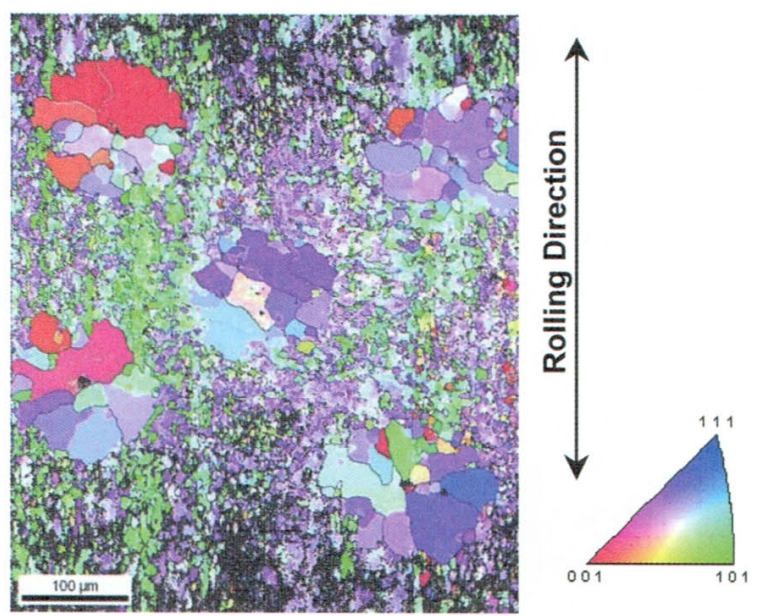

Fig. 6 Five clusters of locally recrystallized grains produced by multi-spot heating on cold rolled pure aluminum plate. $\left(7.0 \times 10^{7} \mathrm{~W} / \mathrm{cm}^{2}-14 \mathrm{~s}\right.$ for each heating.)

が，この結果は，局所加熱では同じ再結晶粒組織を作り 出すことはなく，照射領域固有の局所組織状態を反映し た組織が現れることを意味している。すなわち，照射位 置の選定に当たっては加工組織の状態評価をまず行い, 組織設計に合致した領域を狙う必要がある。このための 組織評価技術の確立もFLASH法開拓のための必要条件と なる。

Fig. 7は局所再結晶粒の方位解析の一例を示している。 照射条件は $1.1 \times 10^{8} \mathrm{~W} / \mathrm{cm}^{2}, 20$ 秒である. Fig. 7 (a) は解析 対象とした領域の結晶方位マップである。図中破線で囲ん だ矩形領域の方位分布を(b)に正極点図法で等高線表示し た。この図ではアルミニウムの冷間圧延特有の集合組織成 分が現れているのがわかる. 一方, 局所加熱により出現し た再結晶粒とそのごく近傍領域のみに対応する正極点図が (c)である。これより，加工組織の持つ方位成分の一部を 受け継いだ再結晶粒が得られたことがわかる.

再結晶現象は加工組織内の一部の比較的転位密度の低 い領域が熱エネルギーの助けを得てその周囲を侵食しな がら進行するものと最近では理解されている. Fig. 7 に示 した再結晶粒はレーザー照射領域内で最も成長のために 有利な条件を有していたと推察される。したがって，特 


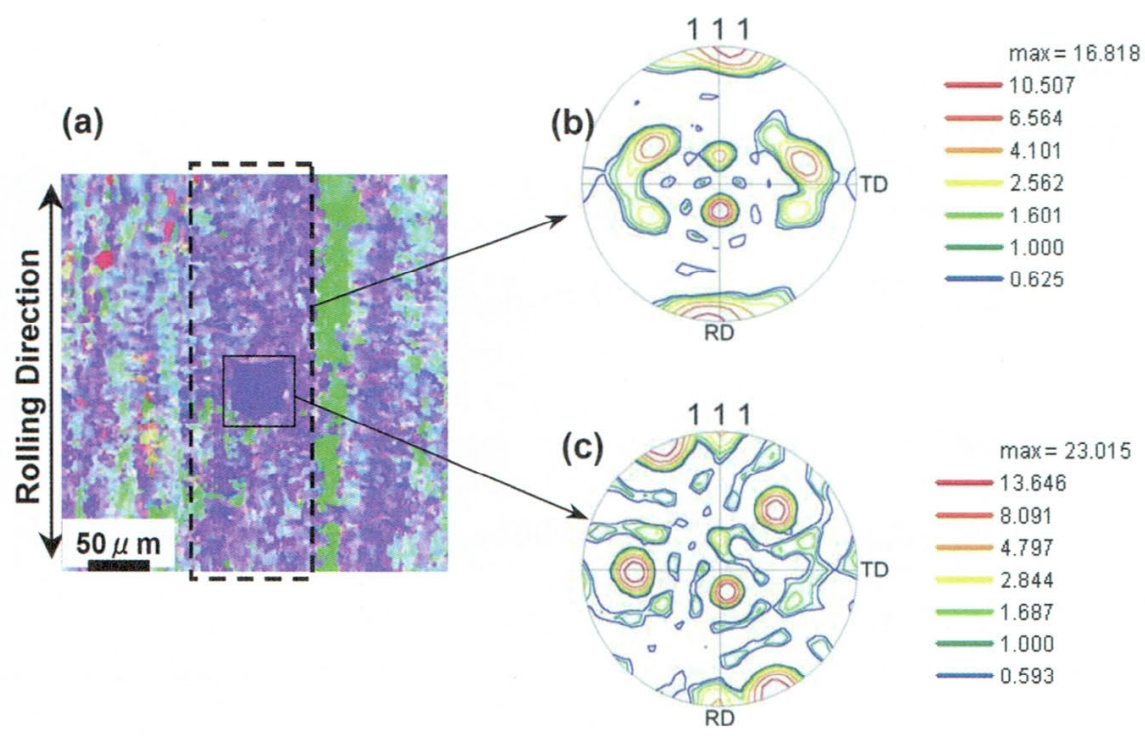

Fig. 7 Orientation distribution of locally recrystallized region in cold rolled pure aluminum plate after the laser-spot heating. (1.1 $\times 10^{8} \mathrm{~W} / \mathrm{cm}^{2}-20 \mathrm{~s}$.) (a) Orientation map of whole measured area. (b) 111-pole figure corresponding to the dashed rectangular area. (c) 111-pole figure from the solid rectangular area containing a locally recrystallized grain.

定の結晶方位のみを選択的に再結晶粒として出現させるに は, 加工組織の評価とターゲットになる領域へのピンポイ ントでの正確なエネルギー輸送が必要になる。これが実現 すれば, 我々は従来の材料プロセスでは得られなかった方 位分布，集合組織を有する素材を創り出せることになる。

\section{6. おわりに}

本稿では筆者のグループが開発してきているレーザー 局所加熱法の背景と意義を述べ，純アルミニウムへの適 用例を紹介した。材料科学・工学の領域でレーザー光を 熱源に用いる研究はすでに報告例があり11)，最近では素 材表面を非晶質化する表面改質技術への適用なども試み られている。しかしながら, 材料組織の不均一性に着目 し, 特定の部位のみを局所的に加熱して特異な組織状態 を創り出すという着想は他に類例がない。組織制御技術 者は単位組織要素々同程度の大きさの領域にのみ選択 的・意図的に光エネルギーを投入する技術を手に入れよ うとしているのである。

数ミクロンあるいはそれ以下の領域に集光する基礎技 術は確立されつつあるが, それを実際のものづくりに適 用するには多くの課題をクリアしていかね杖ならない. 素材に応じて，さらに素材の何を制御するかという目的 に応じて最適なエネルギーを選択するというスマート ビームプロセスの概念を基軸として, 材料組織制御の立
場に立ったユーザーフレンドリーでしかも経済的なレー ザーシステムが我が国独自の技術として創出されること を望む。

局所領域のみを加熱する技術は再結晶組織の創成のみ ならず，他の組織制御にも応用が可能で，本技術のさら なる展開が期待されるところであるが，その実現のため にはレーザー科学・工学と材料学のそれぞれの研究者に よる緊密な連携研究が必要であろう。本稿がそのきっか けとなれば幸いである。

\section{参考文献}

1) 例えば, 堂山 昌夫, 山本 良一編：「材料の組織と機能」(東 京大学出版会, 1988).

2) T. Shibayanagi, M. Tsukamoto, N. Abe, T. Matsumoto, and Y. Soga: Materials Science Forum 558-559 (2007) 329.

3）長嶋 晋一編：集合組織（丸善，1984）。

4) T. Shibayanagi and M. Maeda: Trans. JWRI 32 (2003) 127.

5) K.Matsumoto, T.Shibayanagi and Y.Umakoshi: Acta Mater. 54 (1997) 431.

6) 柴柳 敏哉：高温学会誌 261 (2000) 2835.

7) T. Shibayanagi, N. Matsuda, M. Tsukamoto, N. Abe, and M. Naka: N. Abe, and M.Tsukamoto ed, High Temperature Society of Japan 1 (2006) 143.

8）古林 英一著：「再結晶と材料組織」(内田老鶴围，2000).

9) T. Shibayanagi, M. Tsukamoto, N. Abe, Y. Soga, and T. Matsumoto: Trans. JWRI 35 (2006) 67.

10) 鈴木 清一：まてりあ 40-7 (2001) 612.

11）関 史江, 仲居 道弘, 伊藤 邦夫：軽金属 46 （1996） 231.
EBSP法 (electron back-scatter pattern)

Electron Back-Scatter Diffraction (EBSD) 法とも呼ばれる。 電子線回折図形の一種で, 透過電子顕微鏡 (Transmission Electron Microscopy: TEM) 法における菊池図形と同じ原理 で発生する後方散乱図形(TEMの場合は前方散乱)を走相電 子顕微鏡内に設置した蛍光スクリーンに映し出し，それを 高感度CCDカメラ等でデジタル情報としてコンピュータに
取り込んで自動的に方位解析を行うものである．試料表面 の任意の位置に電子線を照射してパターンを得るが，照射 位置を走査して逐次方位解析を行うことで結晶粒組織と対 応づけられる方位マップを得ることができる。空間分解能 は最高レベルで50 nm径とされており，この場合，加工組 織の解析にも適用可能である.

(柴柳 敏哉) 